\title{
Irish Conservatories
}

\section{during the Inter-War Period}

\author{
Wolfgang Marx \\ Univerzitetni kolidž v Dublinu \\ University College Dublin
}

Like in other English-speaking countries, in Ireland performance, composition and music theory are taught not just in conservatories but also in universities - this is why they have departments of music rather than musicology. All seven Irish universities (as well as the two universities in Northern Ireland) have music departments, and all of them have at least elements of composition or performance as part of their curriculum, although to different degrees. In turn, the Irish conservatories find themselves under increasing pressure to produce quantifiable research. However, at universities there is generally still far more musicological than practical creative work going on, while it is the other way round at conservatories. Undergraduate university programmes in music usually mix aspects of the different areas, while specific degrees in composition or performance can only be earned at postgraduate level - this is different at conservatories.

A second aspect that needs to be mentioned at the beginning is that Irish conservatories are not just involved in third-level music education; they cover music education at every level, from teaching four-year-old beginners to awarding doctorates. To some extent they are not just institutions of higher education but also fulfil the role that municipal music schools (Städtische Musikschulen) occupy in German-speaking lands. This is partly due to their involvement in the nationally used local examination system which I will come back to later. 
A final introductory point is that for a long time the Irish conservatories had no power to confer third-level degrees; they were restricted to awarding certificates and diplomas while at a later stage (beyond the scope of this essay) higher degrees had to be externally approved by a university.

\section{The Inter-War Period in Ireland}

The Irish inter-war period is in many ways quite different from that in other European countries. During the First World War Ireland was still part of the United Kingdom. Unlike in Great Britain (England, Wales, Scotland) there was no conscription in Ireland, yet the British army traditionally included particularly large contingents of Irish and Scottish soldiers. At the same time attempts to break away from British rule continued in Ireland itself, culminating in the unsuccessful Easter Rising in Dublin in April 1916. Yet the real fighting in Ireland itself began after the formal end of the World War, when the Irish War of Independence broke out in January 1919. In 1921, Northern Ireland - with its local Protestant majority - was created, while in 1922 the rest of the island formed the Irish Free State (Saorstát Éireann) which immediately engaged in a year-long Civil War between those who insisted on Northern Ireland being part of the new independent state and those who were in favour of the compromise that had been agreed with the British; the latter side won the war.

When the Second World War broke out Ireland decided to remain neutral (there were still significant animosities towards the British, so becoming an ally of the United Kingdom was out of the question - although many Irish volunteered to join the British army). Ireland had no significant armed forces and could not have contributed much to the war effort anyway, yet its strategic location would have made it a valuable partner for the allies. Today the period of the Second World War is remembered in Ireland as "The Emergency," after emergency legislation that gave the government a closer control of the economy (there was widespread rationing of many goods during and after the war years), also allowing for censorship and other special measures.

All of this means that 1916 and 1922/23 are far more important years in Irish history than any date related to the First or Second World Wars. Gaining independence from the United Kingdom was the most important event in Irish history during the first half of the twentieth century, and this achievement had a huge impact on all levels of society and all institutions, including the conservatories. 
The new Free State quickly published a new syllabus for the school year $1922-23$ as "His Majesty's Statutory Office" was replaced by a Department of Education. It included a complete overhaul of the system, which became significantly broader:

The music curriculum was based on conservatory training, i.e., the education of professional musicians; a strong theoretical orientation underpinned music instruction [...]; a gender bias gradually led to the exclusion of boys from music examinations [...]. ${ }^{\mathrm{I}}$

At second-level it included ear training, "cultivation of taste," music history, development of technique, exercise in creative work, and training in principles of composition. The practical music-making still focused on piano, violin, cello and harp. Irish and Ireland-based composers (such as John Field, Michele Esposito and Herbert Hamilton Harty) began to appear in the syllabus. ${ }^{2}$

There are three conservatories in Ireland: two in Dublin and one in Cork, the republic's second-largest city. They are the Royal Irish Academy of Music (RIAM) and the Conservatory of Music and Drama in Dublin, and the Cork School of Music. Apart from the early days of the RIAM all three of them have always received public funding, although this was never enough to finance all their activities. Let us have a brief look at each of them, with a special focus on the inter-war period.

\section{Royal Irish Academy of Music, Dublin}

The RIAM is the oldest of the three conservatories. It was founded as "Irish Academy of Music" in 1848 (it became "Royal" in 1872, after the Academy made a positive impression on the Duke of Edinburgh, one of Queen Victoria's sons), fundamentally reorganised in $1855 / 6$, and moved into 36 Westland Row, a building in Dublin's city centre that it still occupies today, in 1870. In 1915, the RIAM created room for expansion by buying the adjacent houses nos. 37 and 38 .

In 1870 it also started receiving an annual government grant of $£ 150$ which was increased to $£ 250$ in 1875 and to $£ 300$ in 1880 (on the condition that the Academy would raise at least $£ 100$ through private subscriptions every year). The grant had to be reconfirmed annually by the

1 Marie McCarthy, Passing It On (Cork, Cork University Press, 1999), 94.

2 Stephen S. Lane, "Government Policy on Irish Music Education at Second-Level since 1921,"vol. 1 (MA [Research], Cork School of Music, 2005), 10. 
British parliament. In 1866 the RIAM had 66 students; in 1915 there were 341. These numbers are all contained in the argument made by the RIAM's Governing Body in 1915 against the grant being abolished to aid the war effort, an argument, which was ultimately successful. ${ }^{3}$ It also informs its readers that at that point the Academy was the only institution in Ireland able to award certificates and diplomas in music apart from the universities.

On 6 December 1921, the Anglo-Irish Treaty was signed while on 6 December 1922 the Irish "Free State" came into being; in between those dates an Irish Provisional Government was in power. This transitional period was naturally difficult for institutions such as the conservatories; when in 1922 the members of the RIAM's Governing Body wrote to the Treasury in London to have their annual grant of $£ 300$ renewed they received the following response:

In reply to your letter of the 16 th instant, I am directed by the Lords Commissioners of His Majesty's Treasury to inform you that the question of making a grant to the Royal Irish Academy of Music in the financial year 1922-23 is a matter for the Provisional Government. ${ }^{4}$

The Governors then approached Michael Collins in his capacity as Minister for Finance, asking for the grant to be either continued or increased. In a letter from 13 March the Ministry eventually confirmed a renewed grant of $£ 300.5$ On a later occasion, in 1934, the government did reduce the grant to $£ 100$ without giving a reason but returned it to the original $£ 300$ two years later. However, in 1936 the Ministry of Finance discovered that the RIAM had only raised subscriptions of $£ 86$ 10s rather than the required $£ 100$, so it halved its own grant to $£ 150$ retrospectively. ${ }^{6}$ A "special subscription" organised in response to this yielded only $\mathfrak{E} 7$, or about half the missing amount, so a whip-round was held among Governors until the total of $£ 100$ was reached, with the last $£ 1$ literally being thrown in by

\footnotetext{
"Statement of the Governing Body advancing Reasons against the Proposal of the Lords Commissioners of His Majesty's Treasury that Provision for the Annual Grant of $£ 300$ should not be included in the Estimates to be laid before Parliament for the Year 1916-17," R.I.A.M. Governors, Minute Books, National Archives of Ireland $(1120 / 1 / 24), 56$.

4 Letter from 17 February 1922, Minute Books (1120/1/25), 422.

5 Letter from 13 March 1922, Minute Books (1120/1/26), 4.

6 Meeting on 23 September 1936, Minute Books (1120/1/29), no pagination.
} 
a Governor during the crucial meeting - so the catastrophic loss of $£ 150$ was avoided.?

During the inter-war period the RIAM was dominated by two larger-than-life personalities: Michele Esposito and John F. Larchet. Esposito was an Italian pianist and composer who taught at the Academy for 45 years, from 1882 to 1927, while Larchet taught composition and theory for 35 years, from 1920 to 1955 . Both are good examples of how deeply the Academy and its staff were shaping Dublin's musical life. In 1899 Esposito established and led the Dublin Orchestral Society, while he also was in charge of the chamber music recitals of the Royal Dublin Society. As a composer, he was involved in the Celtic revival, writing an Irish Symphony as well as operas and cantatas on Irish subjects. He was also involved both as composer and adjudicator in the Feis Ceoil (a competitive music festival that had been established in the 189os). Much of this also applied to Larchet, whose activities outside the RIAM included being music director at the Abbey Theatre (Ireland's national theatre), as well as Professor of Music at University College Dublin. In those years the Academy really dominated the classical music scene in Dublin to a much greater extent than it does today.

The RIAM Governors' responsibilities included many details that this kind of body would not necessarily be encumbered by today, such as the discussion and rejection of a contract offer by a Mr Pigott to tune the Academy's 18 pianos for $£ 93$ per year as "exorbitant," the approval of the "recommendation that Harmonic Minor Scales be added to the curriculum for the first class," or an assessment of "the burglarious breaking of a wall at the rear of the R.I.A.M." There are very few references to wars or politics, and where they occur they are rather "indirect." For example, at the first meeting after the Easter Rising the Governors express their "deep sympathy" with the President, Members and Associates of the Royal Hibernian Academy of Arts "in the disaster which has befallen their Society in consequence of the recent disturbances in Dublin" (their building had been completely de-

$7 \quad$ Meetings on 7 and 21 October 1936, Minute Books (1120/1/29), no pagination.

8 Meeting on 5 October 1921, Minute Books (1120/1/25), 383. This turned out to be a wise decision, as the next year the Governors approved a payment of $£ 4210$ s to Pigott for the same service (meeting on 26 April 1922, Minute Books (1120/1/26), 14). Mr Pigott's successors are still in business as the McCullough Pigott music shop today. 
stroyed during the fighting). The "Emergency" that was the Second World War is reflected in an entry like this one:

The Governors definitely decided that during the present emergency orchestral parts were not to be loaned except to the Broadcasting Orchestra but that scores might be loaned for the purpose of study. ${ }^{12}$

More openly political is a motion put to the vote during the early days of the war on 28 February 1940 which proposed

to amend the Scheme under which this institution functions to the extent that the title thereof be amended henceforth to read 'The Irish Academy of Music' or some such other name as the Governors may decide on. ${ }^{\mathrm{I3}}$

Removing the "Royal" from the institution's name would have been a highly visible slap in Albion's face, and it was a very close-run thing indeed: The initial vote was $8: 8$, until the Chairman's casting vote made it 9:8 against the motion. John F. Larchet is recorded as having abstained on this occasion.

Another remarkable motion that captures something of a certain zeitgeist was announced at the meeting of 9 December 1936 for discussion at the subsequent meeting (as was common with all motions):

That all married ladies now on the salaried staff of the Academy be informed by Registered Letter Post, that any contract or Agreement they may hold will become null and void on June 3oth. 1937; and that the Governors in the meantime take steps to appoint men or unmarried ladies in their places, so that the successful candidates may be prepared to take up their duties on the re-opening of the Academy in September 1937. ${ }^{14}$

The motion must have engendered some secret discussions behind the scenes, as it was withdrawn at the next meeting. Yet its thinking was in line with the "Marriage Bar" introduced by Eamon de Valera's new government in Ireland in 1932; this measure required women working in the public service to give up their jobs when getting married. It remained in place for several decades before being gradually abolished (for primary school teachers in 1957; for other public servants in 1973).

\footnotetext{
12 Meeting on 13 October 1943, Minute Books (1120/1/29), no pagination.

13 Meeting on 28 February 1940, Minute Books (1120/1/29), no pagination.

14 Meeting on 9 December 1936, Minute Books (1120/1/29), no pagination.
} 


\section{The Local Centre Examination System}

An important part of the RIAM's activities to this day is the running of the Local Centre Examination System. This is an examination system in music that was devised in the 189os. In 1889 the British "Associated Board of the Royal Schools of Music" (ABRSM) introduced an exam system that by now operates in almost 100 countries. However, Ireland quickly decided that it wanted its own system. The first exams were conducted in 1894 . Initially examinations could only be organised in larger cities (a minimum number of students was necessary to make it viable for an examiner to travel to the local centre), but over time they spread to many smaller places. Today the exams are held all over the island of Ireland (North and South).

The Irish system broadly copied the British one in that it holds examinations in Performance, Music Theory and more recently Speech and Drama. These subjects can be taken in twelve grades of increasing degrees of difficulty, followed by Associate and Licentiate Diplomas in both Teaching and Performance (ARIAM and LRIAM). ${ }^{\text {is }}$ The RIAM defines and regularly redefines the standards for these levels, and also sets the exam pieces for them. The teaching faculty initially provided the majority of the examiners (this was a good way to earn some extra income), and although many of them are still involved in examining today, the majority of examiners are not staff members of the conservatory: 91 examiners and 2 senior examiners, the latter being employed by the RIAM to work on the syllabi for all levels, organise workshops for teachers and examiners and collate and edit the publications which include piano albums, aural test books, theory workbooks, sight reading workbooks and speech and drama workbooks, as well as syllabi. Advised by the examiners, the local centres also organise High Achiever concerts for students who meet specific criteria and marks in the exam.

By taking on the organisation of and indirectly the quality control over the entire system of private music tuition in the country, the RIAM has acquired an enormous influence on the development of art music nationally. In recent years there have been discussions about the representation of Irish composers and of women in the syllabi, with the result that the presence of both groups has been increased in the exams. This means that Irish music students at all levels now encounter a more diverse range of mu-

15 There are up to three preliminary grades (elementary, preliminary and primary - although for some instruments only one of these is on offer), grades 1-8 and the senior certificate above grade 8 (which is rarely used in practice). 
sic than before. Every year the RIAM accepts submissions for new pieces by composers (mostly received by Irish and female composers) for inclusion in the junior piano albums. There is also a composition competition to encourage students under 18 to compose pieces for the piano.

During the inter-war period the Local Centre Examination System grew considerably. While there had been examinations in only three cities in 1894, examinations took place in 19 local centres in 1920, in 37 in 1922, and in 49 in $1924 .{ }^{16}$ The RIAM did not tire of propagating its exam system, as these lines from the annual report of its Governors from 1921 indicate:

The Governors can see no reason why any of the Irish Educational Establishments should send their pupils for examinations to the British Schools and Colleges of Music in this country while the Royal Irish Academy of Music is prepared to carry out this work by highly competent and impartial members of their staff. ${ }^{17}$

As 1921 was the last year of the Irish War of Independence, there may have been patriotic reasons to promote a home-grown system over that of the enemy, but it was also in the RIAM's own interest to secure as much of this lucrative business as possible for itself - and it did. Examining was not always an easy task in those war years; in 1923 - during the Irish Civil War - the Board of Education reported that examiners "will have to go to Clare, Kerry, Cork, Fermoy, Waterford, in motor cars and be fired at impartially by both sides."

In those years $90 \%$ of the examinations were taken by pianists, and this situation provided the stimulus for the RIAM to begin publishing piano books with the exam pieces for grades $1-5$ in 1932. The increase in numbers continued; during the Second World War (in which Ireland was, of course, neutral) it rose from 5623 in 1941 to almost 9000 in 1945 and 10000 in 1949; today up to 40000 students may take these exams every year. ${ }^{19}$

Brian Beckett, "The Local Centre Examination System, 1894-1994," in To Talent Alone: The Royal Irish Academy of Music, 1848-1998, eds. Richard Pine and Charles Acton (Dublin: Gill \& Macmillan, 1998), 297-321.

18 Ibid., 308.

19 I thank Majella Boland, RIAM Senior Examiner, for information on the current numbers in relation to the Local Centre Examination System. 


\section{Cork School of Music}

What is now known as the Cork School of Music started its life in 1878 as the Cork Municipal School of Music, the first of its kind in both Great Britain and Ireland (two years ahead of London's Guildhall School of Music). In its first year it had 161 students who were taught by five staff members. These numbers gradually expanded despite some mishaps - for example, wind instruments were mainly taught by army band members; these classes temporarily collapsed during the Boer War, when the soldiers were transferred to Southern Africa. The School has occupied five different premises during the 140 years of its existence; currently it resides in an impressive, purpose-built building opened in 2007. A Steinway employee in Hamburg once told me that the order for 57 grand pianos for this new building was the largest single order that Hamburg's Steinway factory ever received; they threw in a few free upright pianos for good measure.

On 1 January 1993 the Cork School of Music became a constituent school of Cork Regional Technical College, which in 1997 was renamed as Cork Institute of Technology. This association gave the School degree-awarding powers; it has taught a BMus degree course since 1995, then added taught and research Master's degrees, and awarded its first $\mathrm{PhD}$ in Musicology in 2008. ${ }^{20}$

One of the most important developments during the inter-war period was the School's association with Carl Hardebeck. During the early decades of the twentieth century there was a desire to establish lectureships and professorships of Irish Traditional Music in many places, often funded or partly supported by the local governments. Cork was no exception, and on 3 June 1918 the minutes of the School's Committee (the equivalent of the RIAM's Governing Body) note that the professors had not responded to a request to outline "what was being done for Irish Music in the School."21 The Committee clearly had the impression that the current professors (who were art music specialists across the board) were not interested in furthering Irish music, and might even be blocking attempts to achieve progress with this agenda. At the same meeting one member opined that "until the Committee had seen fit to appoint a Director, having full control of the Pro-

20 Susan O'Regan, "Cork School of Music," in Encyclopaedia of Music in Ireland, eds. Harry White and Barra Boydell (Dublin: University College Dublin Press, 2013), vol. 1: 251-256.

21 Cork, Cork City and County Archives, Cork School of Music, Minute Books of Committee, Meeting on 3 June 1918, Ref. VEC/SM/A/o4, 54. 
fessors, nothing material could be done for Irish Music."22 Shortly thereafter it was decided to create the position of Headmaster and Professor of Irish Music

who would have full control of the Professors and Curriculum and whose duty it would be to incorporate in the syllabus of the various departments an education National in tone. ${ }^{23}$

The headmaster's annual salary was to be $£ 400$, yet the School did not have that kind of money. The solution was an "Irish Traditional Music Fund" which by June 1919 had collected an endowment of $£ 1000$ via public appeals so that the salary could be guaranteed for two years. Meanwhile the professors had learned of the development and peppered the Committee with appeals like the following one in which they were

begging the committee to secure to them in any arrangement which may be made, that neither their status as Professors which they have hitherto enjoyed nor their authority over their classes and the direction of their work will be affected. ${ }^{24}$

The reaction to this indicates a total breakdown of the relationship between Committee and teaching staff: The minutes tersely state that the letter was moved to be marked as "read" before the next item on the agenda is addressed. Two weeks later the Committee voted down by 9:2 a professorial application for a salary increase of $20 \%$. Next, two factions on the committee emerged which started fighting about every detail of the process, reflected in numerous attempts to reword motions, postpone votes, and change minutes - on one occasion several members left a meeting halfway through in protest. This was most likely about one side's attempt to rig the game in order to make sure that the person they preferred was appointed, i.e. Carl Hardebeck, a composer and arranger of Irish music then based in Belfast. This topic appears to have been known all over Cork, as the Committee meeting on 2 July 1919 discussed a letter in which the Cork branch of the "Discharged and Demobilised Sailors and Soldiers" association protested against the appointment of "a German" to the position; ${ }^{25}$ this was before the applicants for the position were officially known even to the Commit-

\footnotetext{
22 Minute Books of Committee, Meeting on 3 June 1918, Ref. VEC/SM/A/04, 55.

23 Minute Books of Committee, Meeting on 13 June 1918, Ref. VEC/SM/A/o4, 56.

24 Minute Books of Committee, Meeting on 17 October 1918, Ref. VEC/SM/A/o4, 6364 . 
tee. Despite his German name Hardebeck was in fact British - the son of a German father who had settled in England and of a Welsh mother, he had at this stage lived in Belfast for 25 years and adopted Irish nationalist views; when the Committee considered his application at its next meeting on 10 July it found that it was written in Irish (the members were provided with an English translation). It turned out that Hardebeck's was the only application received, although there also was "a letter" by Annie Patterson (as the first woman in Ireland to earn a doctorate in music and a specialist on Irish music she was eminently qualified for the position, too) that was ruled not to be an application - one suspects more intrigue going on behind the scenes here than the minutes reveal a century later. ${ }^{26}$ Hardebeck was eventually appointed, but at that very moment a significant number of Professors requested an immediate salary increase of $50 \%$, threatening to otherwise go on strike. After four weeks of negotiations four prominent Senior Professors and one Sub-Professor resigned (more would follow later); the Committee accepted the resignations by a small margin $(3: 2)^{27}$ and over the coming months hired nine new staff members to replace them.

Yet the Hardebeck saga did not end there. After two years in Cork the funds to pay his salary ran out; he agreed to a temporary extension of three months while shortly afterwards being appointed as Professor of Irish Music at University College Cork (for a salary of $£ 100$; this clearly was a parttime position). From April 1922 until July 1923 he acted as Professor of Irish Music (yet not headmaster; this position remained unfilled) at the School once again, but then tendered his final resignation, stating that "his wife is heartily sick of this place and will not spend another Winter in lodgings in Cork." ${ }^{\prime 8}$ Even after he had left the Committee engaged for several years in attempts to raise funds and publish a range of arrangements of Irish music that Hardebeck had written - when this did not materialise Hardebeck wrote many increasingly annoyed letters requesting his work to be returned to him.

In 1936 the full-time position of Director (rather than Headmaster) of the School of Music was created; Bernard B. Curtis held it from 1936 to 1973. Curtis is also the author of a small book commemorating the centenary of the School in 1978 which is an important source of its history. ${ }^{29}$

\footnotetext{
26 Minute Books of Committee, Meeting on 10 July 1919, Ref. VEC/SM/A/o4, 96-98.

27 Minute Books of Committee, Meeting on 6 October 1919, Ref. VEC/SM/A/o4, 111.

28 Minute Books of Committee, Meeting on 23 July 1923, Ref. VEC/SM/A/o4, 266.

29 Bernard B. Curtis, Centenary of the Cork School of Music. Progress of the School 1878 1978 (Cork: 1978).
} 
The student numbers continued to increase, from 300 in the 1930 s to about 800 in the early 1950s. In 1923 the School had 14 teachers, five of whom taught piano, which to this day remains the most popular instrument. There were two teachers of "voice production" (the term then used for singing) and one each for traditional singing, violin, cello, string orchestra, harp, and elocution and drama. Aloys Fleischmann senior (the city's main organist) taught music theory and harmony; with $7 \mathrm{~s} 6 \mathrm{~d}$ per hour he was the highest-paid teacher. His wife, a piano teacher, came next with $6 \mathrm{~s}$ od, while junior piano teachers had to make do with just $2 \mathrm{~s} 6 \mathrm{~d} .^{30}$

Later in the 1920 organ, wind instruments and uilleann pipes (Irish bagpipes) were added to the list of instruments, yet in 1929 (most likely due to the world economic crisis) the salaries went down: Aloys Fleischmann now only earned $6 \mathrm{~s} 3 \mathrm{~d}$, his wife $5 \mathrm{~s}$ od and the lowest-earning piano teacher 2s 1 d. ${ }^{31}$ The old salary levels would only be reached again by the mid-193os, when the numbers of teachers also increased to about 20 while Irish drama, choral classes and a percussion band now appear among the subjects taught. ${ }^{32}$

Unlike its counterpart in Dublin, the Cork Committee had no problem with making political statements, for example on 6 September 1920 when it moved

[t]hat this meeting now stands adjourned as a protest against the action of the British Government in detaining in prison our worthy Lord Mayor against the express wishes of the whole world: which action is typical of the tyrannical attitude of this Government to our Country. ${ }^{33}$

This was at the height of the War of Independence; the Lord Mayor in question was Terence MacSwiney, who had been sentenced to two years in prison in Britain. He was then on hunger strike which would eventually kill him, while making him a martyr as it attracted world-wide attention.

\section{Conservatory of Music and Drama, Dublin}

What is now Dublin's Conservatory of Music and Drama was founded in 1890 to cover an area of music that the RIAM did not engage with, name-

\footnotetext{
30 Cork School of Music, Library, Professor's Day Book 1923-1927, no pagination.

31 Professor's Day Book 1928-1932, no pagination.

32 Professor's Day Book 1932-1936 and 1937-1941, no pagination.

33 Minute Books of Committee, Meeting on 6 September 1920, Ref. VEC/SM/A/04, 156.
} 
ly the tuition of wind and brass bands. This means that it was effectively teaching members of the working classes who were neither financially able to afford classes in the Academy nor did they have time to attend those classes, as most of them were taught during the day. It was agreed that the new "Municipal School of Music" (as it was called for a long time) was to be governed jointly by the Dublin Corporation and the RIAM, and that the RIAM would have musical oversight over teaching and examinations. The Municipal School would not teach piano, organ and singing (which was covered by the RIAM), while Municipal School string classes would be delivered on the premises of the Academy. In 1904 the RIAM withdrew from the co-governance of the School which nevertheless continued to grow. In 1963 it was restructured as a "College of Music," and in 1978 it became a constituent College of the Dublin Institute of Technology (DIT). In 1990 it was renamed as DIT Conservatory of Music and Drama, ${ }^{34}$ and at the beginning of 2019 the Dublin Institute of Technology joined forces with other higher education institutions to become the Technical University of Dublin (TUD), so it is now known as TUD Conservatory of Music and Drama.

When the School left its close association with the RIAM in 1904 it came under the oversight of Dublin City's "Technical Education Committee." This led to a broadening of the syllabus and the inclusion of uillean pipes, Irish war-pipes and pianoforte in its offerings. ${ }^{35}$ The move to new premises (a converted fire brigade station on Chatham Row in Dublin City centre, a venue still used by today's Conservatory even though its main operation has moved elsewhere) helped this expansion. By offering piano and later also singing classes the School gradually entered into competition with the RIAM.

Despite the split in 1904 a relationship between the Municipal School and the RIAM continued; an example of this is John F. Larchet's becoming the Director of the School in 1930. Possibly due to his range of duties in so many other institutions his term was, however, rather short, as in 1931 he was replaced by Maud Devin, who beat senior competitors from both the RIAM and University College Dublin such as Adelio Viani and Robert O'Dwyer to become the first female Director of an Irish conservatory. Devin had to resign from this position in 1934 when she got married

34 David Mooney, "DIT Conservatory of Music and Drama," in Encyclopaedia of Music in Ireland, eds. Harry White and Barra Boydell (Dublin: University College Dublin Press, 2013), vol. 1: 301-302.

35 Tim Cooke, Coláiste an Cheoil / College of Music. A Musical Journey 189o-1993. From Municipal School of Music to Dublin Institute of Technology (Dublin: 1994), 7. 
(another victim of the marriage bar mentioned above). The range of subjects kept expanding, and during the 1930s Carl Hardebeck (who by now lived in Dublin) gave some occasional lectures in the School. The reports submitted by both Devin and her successor Joseph O'Brien attest to their struggles to introduce better standards of examinations across the board, to get the Technical Education Committee to approve more scholarships and generally to increase the grant in the light of continuing increases of student numbers and subject expansions (Devlin introduced elocution and O'Brien harp and organ, utilising the instrument in Dublin Castle's Chapel Royal). ${ }^{36}$ In $1935-36$ the student numbers reached an astonishing 1622, far more than were enrolled at the RIAM or in Cork. ${ }^{37}$ In 1940-41 the teaching staff had increased to 21 (all part-time). Tim Cooke's book on the history of the institution includes many detailed gems of information of this kind, including reference to regular participation in radio broadcasts. All three Irish conservatories engaged early on in collaborations with the new broadcasting stations (regular radio broadcasts commenced in Ireland in 1926). Their students gave live performances on air which had several advantages for them. It gave the performers an additional event to work towards which would reach far more people than any other performance while also increasing the reputation of their institution. Yet it also earned the conservatories some money (the Junior Orchestra of Dublin's Municipal School received $£ 4$ per twenty-minute broadcast in 1940, while students featuring in the series "Our Schools of Music" were paid 5 guineas each)..$^{38}$ In 1945 the increased size of Dublin's Municipal School warranted the appointment of an Assistant Director and four full-time heads of department (a further department, woodwind and brass instruments, was run by the Director of the Army School of Music on a part-time basis). ${ }^{39}$ It appears that the Emergency had not done the development of conservatories in Ireland too much harm.

\section{The Vocational Education Act (1930)}

One of the most important moments for music education in 1920 s and $1930 \mathrm{~s}$ Ireland was the implementation of the Vocational Education Act (VEA) in 1930. At that time primary education was mandatory, while only the well-

\footnotetext{
36 Ibid., 21-23.

37 Ibid., 24.

38 Ibid., 31.

39 Ibid., 38-39.
} 
off in urban areas sent their children to fee-paying secondary schools. The act determined that everybody should have free access to two additional years of education

in preparation for employment in trades, manufactures, agriculture, commerce, and other industrial pursuits, and also general and practical training for improvement of young persons in the early stages of such employment. ${ }^{40}$

This included, for example, music teachers at schools, organists and others who were professionally engaged with music. This was also aided by the fact that

when in 1931 music became compulsory in the primary schools it followed that music should be 'continued' in the second-level vocational school and, as music was a special case, in a Dublin Municipal special School of Music ${ }^{41}$

- that, at least, is how the Dublin Municipal School made its case. Generally, conservatories were best positioned to offer those continuing their education in music tuition in music theory, music history, composition and practical skills; all three institutions quickly developed syllabi (usually at diploma level) and were quite successful in attracting this new clientele. VEA courses became a crucial contributor to the conservatories' budget for many decades to come. Bernard B. Curtis states that the VEA saved the Cork School of Music from its continuing financial worries which occasionally threatened its very existence. He also explains how music was only included as an area covered by the Act at the last minute (and, he claims, "due to the vigilance [...] of the Cork Committee"): During the third and final reading of the bill in parliament the line "including in the country boroughs of Dublin and Cork, music" was added to the Act's list of subjects. ${ }^{42}$ Only this secure financial footing allowed for the expansion of subjects, the appointment of a director, and in the 1950 s the erection of a new building for the School in Cork. cted/en/print.html.

41 Cooke, A Musical Journey 189o-1993, 19.

42 Curtis, Centenary of the Cork School of Music, 39-41. 


\section{Conclusion}

All three Irish conservatories experienced significant growth during the inter-war period; all three benefitted hugely from the Vocational Education Act. Yet all three struggled to cope (particularly financially) with the demands that continuing growth put on them, particularly in an environment that was not too conducive to art music (while the drive towards the inclusion of Irish traditional music lost impetus after independence had been achieved): there was no symphony orchestra in the country, and also no opera house. To this day there is a limited need for classically trained professional musicians in Ireland which is probably one of the reasons why the conservatories remain closely engaged with music education at lower levels alongside the professional third-level tuition.

On the other hand, all three institutions have recently moved or will shortly move to new, larger and more modern premises. While the Cork School of Music opened its new, state-of-the-art building in 2007, the TUD Conservatory of Music and Drama is about to move to a newly built campus in Grangegorman in Dublin. The RIAM also plans a new building to gain additional space and increase the quality of its facilities; building work is meant to commence soon. As the books that have been published about their individual histories indicate, the three Irish conservatories look back proudly at their history, including the inter-war period as a crucial step in their respective developments.

\section{Bibliography}

Beckett, Brian. “The Local Centre Examination System, 1894-1994.” In To Talent Alone: The Royal Irish Academy of Music, 1848-1998, edited by Richard Pine and Charles Acton, 297-321. Dublin: Gill \& Macmillan, 1998.

Cooke, Tim. Coláiste an Cheoil / College of Music. A Musical Journey 189o-1993. From Municipal School of Music to Dublin Institute of Technology. Dublin: 1994.

Cork City and County Archives. Cork School of Music. Library. Professor's Day Book 1923-1927, 1928-1932, 1932-1936, 1937-1941.

Cork City and County Archives. Cork School of Music. Minute Books of Committee. Ref. VEC/SM/A/o4, 54-56, 63-64, 94, 96-98, 111, 156, 266. Cork.

Curtis, Bernard B. Centenary of the Cork School of Music. Progress of the School 1878-1978. Cork: 1978.

Lane, Stephen S. "Government Policy on Irish Music Education at Second-Level since 1921.” Vol 1. MA [Research], Cork School of Music, 2005. 
McCarthy, Marie. Passing It On. Cork, Cork University Press, 1999.

Mooney, David. “DIT Conservatory of Music and Drama.” In Vol. 1, Encyclopaedia of Music in Ireland, edited by Harry White and Barra Boydell, 301-302. Dublin: University College Dublin Press, 2013.

National Archives of Ireland. Minute Books (1120/1/24), (1120/1/25), (1120/1/26), (1120/1/28), (1120/1/29).

O'Regan, Susan. “Cork School of Music.” In Vol. 1, Encyclopaedia of Music in Ireland, edited by Harry White and Barra Boydell, 251-256. Dublin: University College Dublin Press, 2013.

Vocational Education Act, \$3. http://www.irishstatutebook.ie/eli/1930/act/29/enacted/en/print.html. 